\title{
Basic Characteristics Of The Greek Export Enterprises That Penetrate In The Central And Eastern European Countries (CEECS): An Empirical Investigation
}

Stella Karagianni (E-mail: stelkar@uom.gr), University of Macedonia

\begin{abstract}
This paper deals with a particular aspect of Greek export trade with the CEEC countries. More specifically an outline of Greek exports evolution to these countries is being attempted. Parallely, having as a base the data provided through field work - carried out in a representative sample of Greek enterprises active in the area- and with the use of Logit models there, was an attempt to lay out the basic characteristics of Greek enterprises which are progressively increasing their export activity to these countries Through the econometric application we concluded that enterprises which increase progressively their export activity to the CEEC have relatively big size and relatively great export experience. The location as well as the branch of economic activity appears to be of no influence on the export behavior of those enterprises.
\end{abstract}

\section{Introduction}

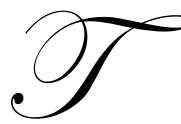

he Greek capital has no experience in trade or production activities at an international level. Historically, the number of companies having production activities abroad was insignificant. Recently things have changed abruptly and international production activities, are now flourishing, mainly in the CEECs, though not exclusively. Greek companies going multinational constitute a novel phenomenon, since in a very short time a large number of investment projects have been initiated abroad. Indeed, until the opening of the CEECs there were less than ten Greek companies with investments abroad. Since then the situation has changed drastically and now we are dealing with a very large number of Greek companies with activities abroad.

In this paper we focus on some aspects of Greece's trade relations with the Balkans, which, have considerably developed since the opening of the CEECs markets. However, these countries still constitute a secondary trade partner of Greece since trade relations with them have started from a very low point. What is of outmost importance, however, is that Greece has significantly more Intra Industry Trade -IIT- with the CEECs than with the EU, which is an indication that there is a greater resemblance of the Greek economy to those of the CEE compared to the economies of the EU countries (See Labrianidis 2000). The importance of Greece's trade with the CEECs and the fact that this is to a great extent IIT $^{1}$ calls for the creation of a "Balkan economic area".

Now there is more optimism concerning the export potential of small and medium sized manufacturing countries (see Nadvi and Schmitz, 1999). Nevertheless there is a clear recognition in the literature that breaking into export markets represents a discontinuous step. Start-up costs are high and this is particularly true when the country as a whole is not on the «export map» (as it is the case with Greece).

The most common and efficient way of accessing foreign markets has been subcontracting manufacturing for foreign customers. Greece has presented again dynamism on this direction, in the sense that, during the 1990s, most of the manufacturing firms investing in the Balkans were in the garment sector doing in that area, some sort of 
subcontracting, of products that have been subcontracted to Greek manufacturers by firms coming from developed countries of Europe. In this sense one might argue that Greece is worth trying to develop towards a «triangle manufacturing» system following the experience of East Asia countries.

Needless to say, as Gereffi (1994) argues, that there is an increasing power of the buyer. The literature has tended to emphasise the benefits of sourcing from low wage countries but has neglected the often-considerable cost of transmitting product and process know - how. Over the recent years, some buyers from developed countries have found a way of overcoming this barrier. New regional intermediaries have been able to grow into it - or were forced into it. Many of the new regional intermediaries are former manufacturers. The most significant example is Taiwanese manufacturers moving to low wage sites in East Asia. Much of the miraculous export success of Mainland China is due to «Taiwan joint ventures». Gereffi $(1994,114)$ has observed such a phenomenon in the garment industry, and refers to it as «triangle manufacturing», in the sense that buyers from developed countries place their orders with the developing country manufacturers they have sourced from in the past, (e.g. Hong Kong or Taiwanese apparel firms) who in turn, shift some or all of the requested production to affiliated offshore factories in one or more low wage countries. (e.g. China, Indonesia or Vietnam). Gereffi emphasises the monitoring function of these companies in the sense that they assure that the buyer's standards in terms of price, quality and delivery schedules will be met by the new contractors in other Third World countries.

In view of the evident perspective that exists for the Greek economy, through the opening of the CEEC markets, the study of the evolution of Greece's export trade with these countries is of particular importance. Even though there are very few papers dealing with this subject ${ }^{2}$. Most of the existing relevant articles deal with Greek investments in the CEEC.

This particular paper focuses on that aspect of Greek export trade activity to the CEEC, which hasn't been investigated enough by other researchers. In particular, there is an attempt to refer to the articulation of the Greek export trade activity to these countries. Furthermore, the basic characteristics of Greek enterprises, with increasing export activity towards these countries, is pointed out here. In the first paragraph, the general aspect of the nature and evolution of Greek export trade towards the CEEC is laid out, based on published and unpublished data coming from the National Statistics Service. In the second and third paragraph, the basic characteristics of Greek enterprises that increase, progressively their export activity towards the CEEC are being determined using the data gathered through fieldwork research carried out on a representative sample of Greek enterprises that are active with exports towards the CEEC) and using the Logit Models.

In the last paragraph, the conclusions of the Paper are being presented.

\section{Export Trade With The CEECs - General Characteristics}

The accession of Greece in the European Union in 1981 and the consequent development and enlargement of the EU, the diminishing importance, at a global scale, of the economic development of the OPEC countries after the reduction of the oil prices in the 80's and the collapse of the socialist system as well as the transition of the central and Eastern European countries (CEECs) to the market economy, constitute the basic reasons, which, after 1980, generated some remarkable rearrangements in the geographical articulation of the Greek export trade. The main characteristic of this rearrangement was the always-greater dependence of the country's export trade on the European Continent. The gradual broadening of the commercial relations between Greece and the CEECs after the collapse of the socialistic system and the accession of these countries to the price-system helped significantly towards this direction.

More specifically, as it can be seen on Table 1, after 1985 and before 1992, the proportion of imports, originating from the EU, to the total imports has increased quite intensively. This increase took place primarily at the expense of the Asian and African countries and secondly at the expense of the CEECs. 
Table 1

Long-term development of the External Trade of Greece by Large Geographical Unities (\%)

\begin{tabular}{|c|c|c|c|c|c|c|c|c|c|}
\hline \multicolumn{10}{|c|}{ Imports } \\
\hline Years & E.U. & E.F.T.A. & C.E.E.C. & Africa & Asia & America & $\begin{array}{l}\text { South Sea } \\
\text { Islands }\end{array}$ & $\begin{array}{l}\text { Rest of } \\
\text { the World }\end{array}$ & Total \\
\hline 1981 & 51,2 & 5,0 & 7,0 & 13,2 & 14,9 & 7,1 & 0,6 & 1,0 & 100,0 \\
\hline 1985 & 48,5 & 4,7 & 9,0 & 10,2 & 20,6 & 5,0 & 0,8 & 1,1 & 100,0 \\
\hline 1986 & 60,2 & 5,1 & 6,5 & 7,4 & 14,6 & 5,1 & 0,9 & 0,3 & 100,0 \\
\hline 1987 & 61,0 & 5,6 & 7,1 & 6,8 & 14,1 & 4,5 & 0,4 & 0,5 & 100,0 \\
\hline 1988 & 65,5 & 6,2 & 6,3 & 4,1 & 10,5 & 6,5 & 0,5 & 0,5 & 100,0 \\
\hline 1989 & 64,7 & 6,2 & 5,9 & 3,9 & 12,1 & 5,9 & 0,4 & 0,9 & 100,0 \\
\hline 1990 & 65,5 & 5,7 & 5,6 & 3,6 & 12,4 & 5,9 & 0,3 & 0,9 & 100,0 \\
\hline 1991 & 62,4 & 5,5 & 5,6 & 4,6 & 14,2 & 6,5 & 0,2 & 0,9 & 100,0 \\
\hline 1992 & 64,6 & 5,4 & 4,4 & 4,8 & 14,5 & 5,0 & 0,3 & 1,0 & 100,0 \\
\hline 1993 & 60,5 & 4,5 & 5,0 & 4,5 & 18,7 & 5,4 & 0,2 & 1,3 & 100,0 \\
\hline 1994 & 64,4 & 5,6 & 6,5 & 4,9 & 12,6 & 4,9 & 0,2 & 0,9 & 100,0 \\
\hline 1995 & 68,3 & 2,1 & 7,3 & 3,3 & 12,2 & 5,7 & 0,2 & 0,9 & 100,0 \\
\hline 1996 & 61,5 & 2,0 & 7,2 & 5,1 & 17,4 & 5,7 & 0,2 & 1,0 & 100,0 \\
\hline \multicolumn{10}{|c|}{ Exports } \\
\hline Years & E.U. & E.F.T.A. & C.E.E.C. & Africa & Asia & America & $\begin{array}{l}\text { South } \\
\text { Sea }\end{array}$ & $\begin{array}{l}\text { Rest of } \\
\text { the }\end{array}$ & Total \\
\hline 1981 & 43,3 & 2,3 & 10,1 & 12,7 & 20,5 & 9,6 & 0,5 & 1,1 & 100,0 \\
\hline 1985 & 53,3 & 3,9 & 8,9 & 6,9 & 14,9 & 9,0 & 0,7 & 2,4 & 100,0 \\
\hline 1986 & 63,5 & 4,1 & 6,3 & 5,4 & 10,5 & 8,3 & 0,5 & 1,5 & 100,0 \\
\hline 1987 & 65,8 & 4,6 & 5,4 & 4,3 & 8,1 & 8,1 & 0,6 & 3,1 & 100,0 \\
\hline 1988 & 64,3 & 5,3 & 5,5 & 4,2 & 10,7 & 7,7 & 0,4 & 2,0 & 100,0 \\
\hline 1989 & 65,2 & 5,3 & 6,7 & 3,7 & 9,1 & 7,3 & 0,6 & 2,3 & 100,0 \\
\hline 1990 & 63,8 & 5,7 & 7,0 & 3,8 & 9,0 & 7,2 & 0,9 & 2,7 & 100,0 \\
\hline 1991 & 63,5 & 5,5 & 6,8 & 3,7 & 9,9 & 7,5 & 0,5 & 2,7 & 100,0 \\
\hline 1992 & 65,4 & 5,2 & 7,1 & 3,6 & 9,9 & 5,5 & 0,5 & 2,9 & 100,0 \\
\hline 1993 & 56,0 & 4,7 & 12,6 & 3,3 & 11,9 & 7,0 & 0,5 & 3,9 & 100,0 \\
\hline 1994 & 53,7 & 4,4 & 13,4 & 3,7 & 12,5 & 8,0 & 0,5 & 3,8 & 100,0 \\
\hline 1995 & 58,8 & 1,7 & 15,6 & 2,7 & 11,3 & 5,5 & 0,5 & 3,9 & 100,0 \\
\hline 1996 & 54,1 & 3,3 & 16,7 & 2,4 & 12,3 & 5,7 & 0,6 & 4,9 & 100,0 \\
\hline
\end{tabular}

Note: (a) The 1996 data involve the $1^{\text {st }}$ Semester and they are provisional, (b) The rest of the world includes the rest of the European countries as well as the confidential countries of the countries code of NSSG, (c) CEECs are characterized all the exsocialistic economies and countries that arose from them.

Source: Labrianidis, L., Kalantaridis, Ch., Karagianni, St., Katsikas, Il. and Ar. Kourtesis, "The Greek Industry and the developments in the Central and Eastern Europe: potentials and perspectives," Research Report for the Ministry of Industry, Vol B (in Greek), 1997.

Simultaneously, during the same period, the geographical articulation of the country's exports is similar. More specifically, after 1985, the percentage of exports to the total exports absorbed by the EU significantly boosted. This boost was brought about at the expense of Asia, Africa and the CEECs.

As far as the percentages of the country's imports and exports to America is concerned, during the same period, the country's imports and exports were kept rather unchanged with the exception of the exports percentage slightly descending inclination. After 1992, the image of the country's imports and exports articulation in terms of geographical unities, was considerably differentiated. The percentages of imports and exports from and to the EU, apart from its important territorial expansion, to the total Greek imports and exports has remarkably decreased. The decrease of these percentages took place primarily in benefit of the CEECs and secondly in benefit of Asia. As a result of this articulation by large geographical unities, which occurred after 1992, an increase of the Greek exports share to the CEECs appeared. Thus, in the course of just three years this share over doubled. 
In relation to the structure of the Greek exports to the CEECs, according to the data of external trade, it can be argued that the primary production products and the consuming goods of the traditional industry (food, drinks, tobacco, clothes and fuels) enjoy a high standing. The exports of dynamic branches of intermediary goods production are almost negligible and they are mainly realized completely fragmentary. It is particularly worth noting that the concentration of the country's exports towards the CEEC's markets, as far as the consuming goods of the traditional industry are concerned, is more intense than the equivalent concentration of the exports to the EU. (Table 2).

Table 2

Comparative image of the Greek external trade structure by the one digit statistical category (1995)

\begin{tabular}{|c|c|c|c|c|}
\hline \multirow[b]{2}{*}{ Commodities Categories } & \multicolumn{2}{|c|}{ Imports from } & \multicolumn{2}{|c|}{ Exports to } \\
\hline & E.U. & C.E.E.C. & E.U. & C.E.E.C. \\
\hline 0. Foodstuffs - Cattle & 15,8 & 4,2 & 20,8 & 20,2 \\
\hline 1. Drinks - Smoke & 2,6 & 0,3 & 3,4 & 12,6 \\
\hline 2. Raw Materials & 2,1 & 11,3 & 6,5 & 7,5 \\
\hline 3. Fuels - Energy & 0,8 & 22,6 & 0,9 & 11,0 \\
\hline 4. Greases and Oils & 0,3 & 0,3 & 8,42 & 0,6 \\
\hline 5. Chemicals & 14,7 & 9,4 & 3,7 & 5,6 \\
\hline 6. Industrial goods & 19,6 & 40,0 & 20,8 & 14,4 \\
\hline 7. Machines & 28,8 & 7,8 & 6,0 & 13,5 \\
\hline 8. Miscellaneous Industrial goods & 14,6 & 3,7 & 26,4 & 13,9 \\
\hline 9. Unclassified & 0,3 & 0,0 & 2,7 & 0.2 \\
\hline Total & 100,0 & 100,0 & 100,0 & 100,0 \\
\hline
\end{tabular}

Source: Same as in Table 1.

One basic characteristic of the export trade of Greece to the CEECs is its uneven distribution in these countries. The largest part of the exports takes place in a very limited number of CEECs.

Only six countries out of 27 CEECs detach over $82 \%$ of the total amount of exports that Greece has realized in 1995 to the CEECs. These countries are Bulgaria (27.35\%), Russia (16.51\%), Albania (15.97\%), Romania $(11.03 \%)$, Ukraine $(6.31 \%)$ and Poland (5.22\%). In this manner, 21 countries detach a percentage that comes close to almost $20 \%$ of the total exports of the country to the CEECs. It is though an impressive fact that only three countries of the Balkans absorb over $50 \%$ of the total exports. Boulgaria enjoys a dominant place among these countries, since on its own it absorbs approximately $30 \%$ of the Greek exports to the CEECs. (Table 3)

As far as the imports sector of Greece from the CEECs is concerned, the concentration of shares is even more impressive. The countries that exceed an import share of 5\% are only four and their total participation reaches $78.4 \%$. This concerns the following countries: Bulgaria with a share of $28.6 \%$, Romania with a share of $7.45 \%$, Czechoslovakia with 5.1\% and Russia with 39\%. If the Ukraine's share (4.89\%), which is close to 5\%, is also added, we conclude that only five CEECs out of 27 supply Greece with $83 \%$ of the equivalent imports. In this way, four out of the five greater and the six greater clients of the country are common (Bulgaria, Romania, Russia, Ukraine) whereas Czechoslovakia takes the place of Poland when imports are concerned. The sixth country is Albania, which appears to be important only as far as the export share of the country to the CEECs is considered ${ }^{3}$.

Considering the last remark as a fact, one could argue that the vicinity of Greece to each of the CEECs plays a decisive role in determining the rate of its exports towards these countries. The geographical position is highlighted as an important factor, above all others, for the imports development. Of course, specifically in this case, the geographical factor is a prominent one considering the nature of the exporting goods, which in their majority are fuels, delicate primary production commodities and traditional industrial products. 
Table 3

External trade of Greece with the CEECs by zones and by country in 1995 (in drachmas and in \%)

\begin{tabular}{|c|c|c|c|c|}
\hline & Imports & $\%$ & Exports & $\%$ \\
\hline Total & 417.577 .812 .778 & 100,0 & 378.881 .557 .833 & 100,0 \\
\hline Zone A & 155.519 .185 .424 & 37,24 & 219.447 .855 .913 & 57,92 \\
\hline Albania & 8.687 .346 .395 & 2,08 & 60.502 .631 .103 & 15,97 \\
\hline Bulgaria & 112.084 .278 .832 & 26,84 & 103.618 .339 .485 & 27,35 \\
\hline Romania & 31.098 .041 .375 & 7,45 & 41.781 .477 .837 & 11,03 \\
\hline FYROM & 3.397 .893 .664 & 0,81 & 8.494.205.343 & 2,24 \\
\hline Serbia \& Montenegro & 251.625 .158 & 0,06 & 5.051 .202 .145 & 1,33 \\
\hline Zone B & 59.256 .794 .674 & 14,19 & 45.286 .987 .322 & 11,95 \\
\hline Czsech Republic & 21.338 .601 .980 & 5,11 & 12.363.373.606 & 3,36 \\
\hline Slovakia & 7.034 .012 .938 & 1,68 & 2.234 .997 .132 & 0,59 \\
\hline Poland & 15.368 .210 .692 & 3,68 & 19.782.871.257 & 5,22 \\
\hline Hungary & 15.515 .969 .064 & 3,72 & 10.905 .745 .327 & 2,88 \\
\hline Zone C & 185.533 .361 .188 & 44,43 & 89.027 .799 .160 & 23,50 \\
\hline Russia & 162.893 .298 .303 & 39,01 & 62.548 .462 .946 & 16,51 \\
\hline Ukraine & 20.410 .814 .722 & 4,89 & 23.916.059.492 & 6,31 \\
\hline Moldavia & 1.181.817.269 & 0,28 & 1.828 .464 .844 & 0,48 \\
\hline Belarus & 1.047 .430 .894 & 0,25 & 734.811 .878 & 0,19 \\
\hline Zone D & 1.518 .400 .189 & 0,36 & 6.066 .785 .666 & 1,60 \\
\hline Georgia & 1.246 .438 .948 & 0,30 & 3.524 .220 .899 & 0,93 \\
\hline Armenia & 19.934 .552 & 0,00 & 2.021.908.230 & 0,53 \\
\hline Azerbaijan & 252.026 .689 & 0,06 & 520.656 .537 & 0,14 \\
\hline Zone E & 4.425 .598 .668 & 1,06 & 3.873 .897 .509 & 1,02 \\
\hline Uzbekistan & 705.072 .194 & 0,17 & 901.409 .971 & 0,24 \\
\hline Tanzikistan & 717.141 .706 & 0,17 & 40.109 .415 & 0,01 \\
\hline Kazakhstan & 216.346 .084 & 0,05 & 2.322 .556 .441 & 0.61 \\
\hline Turkmenistan & 2.752 .637 .691 & 0,66 & 265.825 .203 & 0,07 \\
\hline Kyrgyz & 34.400 .993 & 0,01 & 343.996 .479 & 0,09 \\
\hline Zone F & 833.244 .167 & 0,20 & 1.601 .404 .639 & 0,42 \\
\hline Estonia & 328.165 .71 & 0,08 & 222.792 .812 & 0,06 \\
\hline Leetonia & 172.710 .612 & 0,04 & 383.461 .580 & 0,10 \\
\hline Lithuania & 332.367 .684 & 0,08 & 995.150 .247 & 0,26 \\
\hline Zone G & 10.491 .228 .469 & 2,51 & 13.576 .827 .624 & 3,58 \\
\hline Slovenia & 6.921 .654 .880 & 1,66 & 10.325 .035 .395 & 2,73 \\
\hline Croatia & 3.287 .028 .914 & 0,79 & 3.195 .507 .104 & 0,84 \\
\hline Bosnia Herzegoviana & 282.544 .675 & 0,07 & 56.285.125 & 0,01 \\
\hline
\end{tabular}

Source: Same as Table 2 .

The analysis so far, has been based on published and unpublished data of the NSSG, and has provided us with a general but precise image of the nature and course of the Greek exports to the CEECs during the last years. Nevertheless, this image is so general, that it makes it impossible, given the structure of the Greek industry and the economy as a whole, to draw clear conclusions, useful to the formation of an effective state policy, which will further invigorate the export trade of the country to the CEECs.

\section{Basic Characteristics Of The Enterprises That Exercise Export Activities To The CEECs}

In order to deduce lucid conclusions, capable of supporting the exercise of an effective export policy, it is essential to pinpoint the basic characteristics of the Greek enterprises, which are increasing progressively their export activities to the CEECs markets. In order to pinpoint these characteristics, the field research has been considered to be of crucial importance, given the fact that the published and unpublished secondary data available for this purpose are absolutely insufficient. More specifically, questionnaires have been addressed to a sample of Greek enterprises, which have export activity to these countries. The selection of this sample was random among all the Greek enterprises (producing and commercial), which deal with the promotion of commercial products and realize exports 
to the CEECs. Out of 148 enterprises of the sample, occupied with exports to the CEECs, $105-$ that is $70.5 \%$ of them - are producing units, which also deal with commerce, while 44 - that is $29.5 \%$ of them - are commercial units. This is in equivalence with the 4966 enterprises in both categories (3103 producing and 1863 commercial), which have export activities to the CEECs for the year 1995, according to ICAP ${ }^{4}$.

Based on the field research that has taken place during the first semester of 1997, it is deduced that a great number of enterprises that export to the CEECs are occupied exclusively with exports to the CEECs markets. More specifically, out of 148 enterprises of the sample that export to the CEECs, only 75 - that is $51 \%$ - export to other world markets as well, while the rest 73 - that is $49 \%$ - limit their exports only to the CEECs. In addition, the greatest part of the exporting enterprises, whose exports are destined exclusively towards the CEECs, involves commercial enterprises. The producing enterprises that deal with exports to the CEECs markets seem to spread their export activities to other countries as well. From a sample of 148, there comes out, that $86 \%$ of the commercial enterprises export exclusively to the CEECs, while only $14 \%$ of them export to other countries as well. Thus, there is an explicit potential of the commercial enterprises to develop themselves in a biased way in terms of the CEECs. Additionally, similar conclusions are derived through the evaluation of the data that refer to the 4966 enterprises that are recorded by the ICAP as enterprises that are activated in CEECs exports. [Details are given in L.Labrianidis et.al. (1997)]. The percentages of the commercial enterprises are formed to $36.5 \%$ and $63.5 \%$, respectively. (Table 4)

Table 4

Areas of export activity depending on whether it concerns producing or commercial enterprises in Greece. (in \%)

\begin{tabular}{|c|c|c|c|}
\hline & Only CEECs & CEECs and elsewhere & Total \\
\hline Commercial & $86 \%$ & $14 \%$ & $100 \%$ \\
\hline Producing (1) & $36.5 \%$ & $63.5 \%$ & $100 \%$ \\
\hline Total & 73 & 75 & 148 \\
\hline
\end{tabular}

Source: Same as Table 3.

The above observations support the hypothesis that the product composition of the trade with CEECs will probably respond to the relative factor endowments underlying current trade patterns.

\section{Empirical Analysis}

Apart from the basic observations presented above and from which some conclusions about the features of the Greek export enterprises to the CEECs markets can be drawn, the crucial question dealing with the basic characteristics of the enterprises, which through time increase their export activity towards these markets, still remains. In order to answer this question, a number of assumptions has been set concerning the size of the enterprise, its exporting experience, its location, the development of its export activity through time, the branch of its economic activity etc. An attempt has been made to examine the accuracy of these assumptions through specific questions included in the questionnaire that the field research addressed to each enterprise. For each particular assumption relevant question were formulated. Given the fact that $95 \%$ of the questionnaire's questions involved qualitative data, for the econometric exploration of the enterprises' characteristics, (which through time increase their exporting activity to the CEECs) the models LOGIT have been used. (Demaris A. (1992), Maddala S. (1983)).

The econometric research that has been attempted, based on the questionnaires' records, involved the development of the export activity of the enterprises activated towards the CEECs. More specifically, it has been examined, how the increasing trend of the enterprises' export activity is affected from a) the size of the enterprise, measured by the number of its employees b) the number of the enterprise's export activity years c) its location and d) the economic activity branch. So there was an attempt to reveal the characteristics of the enterprises, which positively influence the increasing trend of exports towards the CEECs. 
The form of the model that has been used for the above purpose is:

$\mathrm{x}_{1}=\alpha+\beta \mathrm{x}_{2}+\gamma \mathrm{x}_{3}+\delta \mathrm{x}_{4}+\varepsilon \mathrm{x}_{5}$

where $\mathrm{x}_{1}$, the dependant variable, is the logarithm of the probability that the development of exports will be upward.

The dependant variable $\mathrm{x}_{1}$ (export development to the CEECs) takes value 1 if the exports were upward, and 0 if they were not upward.

The variable $\mathrm{x}_{3}$ (years of the enterprise's export activity) takes value 1 if the number of the export activity years were 0-7 and 0 if the enterprise's export activity exceeds 8 years. The basic criterion for grouping the years of export activity to these two basic groups was the fact that the transition of the CEE economies to the free-market system began approximately 7 years before the distribution of the questionnaires. This variable is used in order to check how the export experience, measured by the years of export activity, of either producing or commercial enterprises, positively affects the upward trend of the enterprises' export activity towards the CEECs markets.

The variable $\mathrm{x}_{4}$ (enterprise location) takes the value 1 if the enterprise location is in the Macedonia-Thrace region and 0 if it is located elsewhere in Greece. The basic criterion for this grouping was the geographical proximity of Northern Greece to some of the CEECs markets. This variable is used to check the hypothesis if Northern Greece's enterprises - which have a comparative advantage related to the other Greek regions' enterprises, due to their geographical proximity to the CEECs markets - positively affect the increase of the export activity, to these countries, through time.

The variable $\mathrm{x}_{5}$, which refers to the economic activity branch of each enterprise, takes the value 1 for enterprises, which belong to the foodstuffs and drinks branch, and 0 for the rest of branches. The basic criterion for grouping the economic activity branches in two groups was the fact that the greater part of the country's exports towards these countries, given the NSSG data, are mainly delicate consumer products. This variable is used to check the hypothesis that the type of products, which are exported, affects the course of the enterprises' export activity to the CEECs.

Finally, the variable $\mathrm{x}_{2}$, the unique qualitative independent variable, represents the number of enterprise's employees and shows the relative size of the enterprise. This variable is used to check the hypothesis whether the size of the enterprise, measured by the number of its employees, affects the upward course of the enterprise's export activity to the CEECs markets.

A priori, $\beta$ and $\gamma$ are expected to be positive, and $\delta$ and $\varepsilon$ to be positive or negative. By estimating the model above, using the method LOGIT, the following results, illustrated on Table 5, came out. From this table we observe that $\mathrm{x}_{5}$, which refers to the activity of each firm, is not statistically significant, and $\mathrm{x}_{4}$ (firm's location) is only marginally significant.

Table 5

Dependant variable $x 1$ (exports development) 148 observations

\begin{tabular}{lcccc}
\hline Regressor & Coefficient & Standard Error & T-Ratio & {$[$ Prob] } \\
x2 & -.66610 & .38706 & -1.7209 & {$[.088]$} \\
x3 & .0039105 & .0019482 & 2.0073 & {$[.047]$} \\
x4 & -.43163 & .33484 & -1.2891 & {$[.200]$} \\
x5 & .17954 & .51786 & .34670 & {$[.730]$} \\
\hline
\end{tabular}

Maximized value of the log-likelihood function $=-63.7701$

Pseudo-R-Squared $=.10679$ 
By removing the last variable $\left(\mathrm{x}_{5}\right)$ from the model as statistical insignificant and by reestimating the model, the following results, illustrated on table 6 , arise.

Table 6

Dependant variable $x_{1}$ (exports development)

148 observations

\begin{tabular}{lcccc}
\hline Regressor & Coefficient & Standard Error & T-Ratio & {$[$ Prob] } \\
x2 & 1.1927 & .36146 & 3.2997 & {$[.001]$} \\
x3 & .0024793 & .0017381 & 1.4264 & {$[.157]$} \\
x4 & .48071 & .42166 & 1.1400 & {$[.257]$} \\
\hline
\end{tabular}

Maximized value of the log-likelihood function $=-63.9778$

Pseudo-R-Squared $=.10388$

As expected from the above table, the estimated coefficients have the a priori expected signs, and most are statistically significant. The results, for example, indicate that the larger the size of the firm the higher the export capability of that firm. Similarly, the positive coefficient on $\mathrm{x}_{3}$ suggests, ceteris paribus, that the enterprise more likely has increased export activity.

As a final conclusion from the econometric application, which has preceded the characteristics of the Greek enterprises, which exercise export activities to the CEECs, it arises that:

The enterprises that increase their exporting activity to these markets are relatively large enterprises (their size has been determined by the number of their employees), which have relatively great exporting experience, accruing from the fact that they also export, to other countries except for the CEECs, while simultaneously their exporting activity holds for more than 7 years. The location of the exporting enterprises does not seem to influence the increase of the exporting Greek enterprises to these countries. A similar conclusion can be drawn, as far as the influence of the location to the exports is concerned, by examining the relative data that refer to the total number of enterprises that exercise export activities to the CEECs markets and they are registered to the ICAP (For details see Labrianidis 1997). Finally, the economic activity branch, to which the export enterprises belong, seems to have no influence on the Greek exports development to these countries. ${ }^{5}$

\section{Conclusions}

After the opening of the CEE countries Greek exports to that area had a sudden boost, even though the percentage of these exports compared to the total of Greek exports towards the EU countries remains very low.

The export goods to the CEEC are mostly primary production products and consuming goods of the traditional industry (food, drinks, tobacco, cloths.). The exports of dynamic production branches of intermediary goods are almost negligible and they are being realized in a totally fragmentary level. The major part of these exports concerns a very limited number of the CEE countries. Only 6 countries (Bulgaria, Romania, Albania, Ukraine and Poland) absorb a percentage that reaches higher than $82 \%$.

Through the econometric application it became clear that the Greek enterprises that are increasing their export activity to the CEEC are relatively big in size and have also a relatively important exporting experience. The location of the enterprise as well as the economic activity branch appears to be of no influence on the export behavior of these enterprises.

All the above conclusions, considered jointly with the existing structure of Greek Industry (many small in size and not-well organized enterprises) support the idea that future development of the exports cannot be 
guaranteed. Undoubtedly, enterprises that penetrate with export activities in the CEEC should be restructured aiming at the exploitation of the economies of scale, while establishing and improving their competitive position.

This is because, apart from all, the stable development of these countries will provoke inevitably the development of the traditionally industrial branches, either through direct foreign investments from abroad - aiming at the local market - or through the process of modernization and readjustment of the previous industrial system to the new one.

The state policy that will aim at the increase and conservation of the Greek export industries to the CEECs should be such that it guarantees the restructuring and the modernization of the enterprises and that it will not be supported by export subsidies and every type of tax reductions which may yield short term and marginal results. Of course, the formulation of specific premises about the implementation of an effective industrial policy by increasing the exports to the CEECs departs from the aims of this paper.

\section{Endnotes}

1. For more details on Intra-idustry trade see: Davis, D., R., "Intra-industry trade: A Heckscher-Ohlin-Ricardo approach," Journal of International Economics, Vol. 39, pp. 201-226, 1995; Nilsson, L., "The Measurement of Intra-Industry Trade between Unequal Partners," Weltwirtschaftliches Archiv, Vol. 133, No 3, pp. 555-565, 1997; Rajan, R., S., "Measures of Intra-Industry Trade Reconsidered with Reference to Singapore's Bileteral Trade with Japan and the United States," Weltwirtschaftliches Archiv, Vol. 132, No. 2, pp. 379-389, 1996; and Torstensson, J., "Determinants of Intra-Industry Trade: A sensitivity Analysis," Oxford Bulletin of Economics and Statistics, Vol. 58, No. 3, pp. 507-524, 1996.

2. Kyrkilis, D. and E. Nicolaidis, "Trade Flows between Greece and Eastern Europe: Inter-Industry VS. IntraIndustry Trade," Rivista Internationale di Scienze Economiche e Commerciali, Vol. 45, No. 1, pp. 139-150, 1998; Labrianidis, L., "Greek trade relations with the Balkans in the 1990s," Proceedings of $1^{\text {st }}$ International Conference on Recent Economic Development and Problems in the Transition Economies, AICEG, 2000; and Petrakos, G., "A European macro region in the making? The Balkan trade relations of Greece,” European Planning Studies, Vol. 5, No. 4, pp. 515-533, 1997.

3. For the determination of the boundaries in 7 different zones, in which all CEECs appear, economic but mainly geographic criteria have been used. The countries which have similar economic characteristics and which are at the same geographical area have been grouped together.

4. According to the catalogue and the classification that ICAP follows and it refers to 1995, there are 5049 Greek enterprises, which realise exports to the CEECs. The enterprises that involve information, transport, supply services etc. have been removed from this catalogue and the rest have been grouped in two categories, producing and commercial, and they are occupied with the promotion of commercial products.

5. In this study we considered only 24 economic activity branches, grouped in two categories.

\section{References}

1. Demaris, A., "Logit Modeling: Practical Applications”, Saye Publications, California, 1992.

2. Gereffi, G., "The organization of buyer-driven global commodity chains", In: G.Gereffi and M.Korzeniewicz (eds) Commodity chains and Global Capitalism. Praeger, Westport, pp. 95-122, 1994.

3. Gual, J. and C. Martin, "Trade and FDI with CEEC: its impact on Spain", CEPR, Discussion paper, 1994.

4. Labrianidis, L. Th. Kalogeresis, "Greek Trade relations with the Balkans in the 1990s", Proceedings of $I^{\text {st }}$ International Conference on Recent Economic Development and Problems in the Transition Economies, AICEG, 2000. 
5. Labrianidis, L., Kalantaridis, Ch., Karagianni, St., Katsikas, I. and Ar. Kourtessis, "The Greek industry and developments in Central and Eastern Europe", Research Report for the Ministry of Industry (in Greek), 1997.

6. Labrianidis, L., Kalogeresis, Th., Karagianni, St., Katsikas, I. and St. Mavroudeas, "The economic implications for the development of Greece and northern Greece in particular, due to the opening of the Greek industry to the Balkans", Research Report for the General Secretary of Research and Thechnology (in Greek), 1998.

7. Maddala, S., "Limited Dependent and Qualitative Variables in Econometrics", Cambridge University Press, 1983.

8. Nadvi, K. and H. Schmitz (eds.), "Industrial Clusters in Developing Countries", Special Issue of World Development, Vol. 27(9), 1999.

Notes 